\title{
Concentric Fibrosis of Intrahepatic Duct
}

National Cancer Institute

\section{Source}

National Cancer Institute. Concentric Fibrosis of Intrahepatic Duct. NCI Thesaurus. Code C111787.

A morphologic finding indicating the presence of fibrosis around an intrahepatic bile duct in the liver tissue. 